\title{
A Pannon vegetációrégió lehatárolása
}

\author{
FEKETE Gábor ${ }^{\dagger *}$, KIRÁLY Gergely ${ }^{1}$ és MOLNÁR Zsolt²** \\ ${ }^{1}$ Soproni Egyetem, Erdőművelési és Erdővédelmi Intézet, \\ 9400 Sopron, Ady E. u. 5.; kiraly.gergely@uni-sopron.hu \\ ${ }^{2}$ MTA Ökológiai Kutatóközpont, Ökológiai és Botanikai Intézet, \\ 2163 Vácrátót, Alkotmány u. 2-4.; molnar.zsolt@okologia.mta.hu
}

Elfogadva: 2017. április 20.

Kulcsszavak: bennszülött növénytársulások, flóra, pannon vegetációtípusok, potenciális növényzet, Quercetum petraeae-cerridis, zonalitás.

Összefoglalás: A Pannonicum szinte minden európai-eurázsiai biogeográfiai térképen önálló florisztikai egységként szerepel. A pannon régió azonban vegetációs szempontból is egyedi. Dolgozatunkban a potenciális növényzet alapján adunk javaslatot a Pannon vegetációrégió határának meghúzására. A régió határvonalát Európa potenciális vegetációtérképére, mint közös platformra húztuk be. Az alapadatokat föként a szerzők terepi tapasztalatai, valamint a régióra készült vegetációtérképek és vegetációjellemzések biztosították. Azokat a tájakat vontuk a Pannon vegetációrégióhoz, amelyek növényzete dominánsan pannon jellegü, azaz jellemzően a nagy kiterjedésủ klímazonális és edafikus pannon társulásokat használtuk a határ megvonására. A felvázolt határ többnyire a Quercetum petraeae-cerridis és a Carpinus betulus/Fagus sylvatica-uralta erdők között húzódik. Minden jelentősebb határszakasz esetében megadtuk, hogy a határvonal két oldalán mi a jellemző növényzet. Ha egy pannon jellegủ társulás vagy társulásmozaik teljesen körülölelt más, kisebb kiterjedésủ Carpinus betulus/ Fagus sylvatica-uralta tájat/tájrészletet, azt a pannon régió részének tekintettük. Az így lehatárolt Pannon vegetációrégió $167012 \mathrm{~km}^{2}$ kiterjedésű. A határvonal DK-Morvaországtól a Fertőtől nyugatra halad, átmetszve a Dunántúl nyugati és déli részét éri el a Drávát, majd a Fruška Gora-t és a Delibláti-homokpusztát északról megkerülve, a Maros-völgybe behatolva, az Erdélyi-szigethegység nyugati lábán haladva éri el a Tisza és Bodrog árterét. Északon a Kárpátok előhegyeinek Quercetum petraeaecerridis erdőinek északi szegélyén haladva zárul a kör. Vannak olyan szakaszok, ahol a határ behúzása egyértelmű, máshol a határ nem teljesen egyértelmű, mivel jellegtelenebb és/vagy azonális növényzetű tájakban a határbehúzást csak önkényesen lehetett megtenni. A Pannon vegetációrégió határa nyugaton-délnyugaton kevésbé, északon és keleten jobban egybeesik a Pannonicum flóratartomány határával. Az ok a florisztikai Pannonicum térbelileg olykor pontatlan határbehúzása mellett a flóra és a vegetáció eltérő viselkedése, a határokon a grádiensek eltérő meredeksége, ill. az extrazonalitás eltérő hatása. A jövőben érdemes lenne elvégezni a szomszédos vegetációrégiók lehatárolását hasonló elvek alapján. Kiderülhet, hogy mennyire általános jelenség a régiók közé ékelődő, jelleg nélküli térségek vagy éppen átmeneti jellegủ vegetációval borított területek létezése, hasonlóan a DNy-Dunántúlhoz. Fontos feladat lenne kvantitatív adatok alapján pontosítani a Pannonicum flórarégió határát, felvázolva a határmenti flóragrádienseket. Térképünk arra is lehetőséget ad, hogy az Európai Unió Natura 2000-es és egyéb programjai tudományosabb alapokon álló biogeográfiai lehatárolást alkalmazzanak.

* A tanulmány Fekete Gábor Tanár Úr halála után került sajtó alá, de a szakmailag végleges anyagot még Tanár Úrral együtt hármasban készítettük el, azóta csak szerkesztési, formázási javítások történtek. ** Levelező szerző. 


\section{Bevezetés}

\section{A pannon flóratartomány}

Az első, hazánkat érintő tudományos flóramű szerzője, a németalföldi Clusius fellépésétől (a 16. század végétől) három évszázadra volt szükség (a 19. század végéig), hogy a Kárpát-medencei flóra feltárását - beleértve a tudományra új taxonok leírását - nagy vonalakban elvégezzék. Komolyabb növényföldrajzi megállapításokra csak ezután kerülhetett sor (GoмBocz 1936). A botanikusok hamar felismerték a Kárpát-medence belső térsége flórájának egyedi jellegét. A pannóniai flóravidék kifejezést már Anton Kerner használja (KERNER 1887) - igaz, a pontuszi flórabirodalom részeként, hogy a magyar Alföld fátlanságától indíttatva ezzel is a keleti flórakapcsolatok fontosságát hangsúlyozza. Borbás Vince a pontuszi kapcsolatoknak, a keleti flóra-rokonságnak Kernerrel szemben kisebb jelentőséget tulajdonít, és a magyar (pannóniai) flóravidék bennszülött fajokon nyugvó önállóságát emeli ki (BorBÁs 1896). Ennek a magyar flóravidéknek a kiterjedését is durván felvázolja növényföldrajzi beosztásában, észrevéve a fennálló flórakapcsolatokat: értelmezésében a Magyar-középhegység és az Alföld együtt teszik ki a magyar flóravidéket. Borbás a Kárpát-medencei flóra tagolásának több koncepcióját is papírra vetette (pl. BORBÁs 1905). Ennek a flórának a területi differenciálódásáról, megoszlásáról rajta kívül több neves botanikus is kifejtette elképzelését már a 19. század végétől kezdve; ezt számos flóra-beosztási térkép tanúsítja (KERNER és Wettstein 1888, Rapaics 1910, Simonkai 1910, Tuzson 1915, teljesebb felsorolást lásd: Soó 1933). SimONKAI térképe Borbáshoz képest visszalépés azzal, hogy nem ismeri fel a középhegységek és az Alföld florisztikai rokonságát. Fontos fejlemény, hogy Rapaics (1910) teljes körben meghúzza a Dunai flórajárás (durván a mai Pannonicum) határát; az Északi-Kárpátok és az Alpok felé mai szemmel is reálisan. A magyar flóravidék kielégítő flórageográfiai leírásának elemi feltétele a teljes flóra taxonómiailag megbízható listázása volt. Ez Jávorka Sándor nagy flóraművével (JávorKa 1924-1925) teljesedett ki. A Kárpát-medence flórájának ma elfogadott növényföldrajzi beosztását a Jávorka ugyanebben a müben közölt térképe alapozta meg. A továbblépés Soó Rezső nevéhez füződik, aki az akkori növényföldrajzi tudás szintetizálásával, nagy intuícióval a történelmi Magyarország flórájának (benne a pannóniai flóra, a Pannonicum mint flóratartomány) olyan részletgazdag beosztását szerkesztette meg, amelynek máig tartó hatása van (Soó 1933).

A fentiekből is kitünik, hogy a pannon flóra értelmezése kapcsán a kérdések három csoportja jelentkezik: 1 . a flóra hatáskörzete, kiterjedése, elhatárolása; 2. e határokon belül a flóra területi variabilitása, ennek megfelelő felosztása; végül 3. a flóra rokonságának (hasonlóságának) nagytérségi vonatkozásai, azaz a flóra besorolása a flórageográfiai területi hierarchia nagyobb egységeibe. 
1. A flórageográfusok a teljes flóratartomány külső határaira mindeddig nem fordítottak megfelelő figyelmet. Azt régóta tudjuk, hogy a pannon flóra nem áll meg a medence szélénél. KERNER felejthetetlen művében („Pflanzenleben der Donauländer") például már 1863-ban hírt ad a pusztai sztyeppflóra Morvamezőig vagy a Wachau-ig nyomuló előőrseiről. Kétségtelen, hogy a külső határ északnyugati, északi szakasza a legjobban kutatott, ezért a közölt határvonalak megbízhatóak (lásd Dostál 1960, Niklfeld 1964, Futák 1966). A tudásanyag ezzel szemben több szakaszon (pl. DNy-i határ) a mai napig hiányos, vagy az egységes megítélés hiányzik. Soó Rezső az egyetlen, aki vállalkozott a pannon flóra Kárpát-medencén túlnyúló határainak körkörös felvázolására (Soó 1933, 1947).

2. Annál számosabbak a belső határokra irányuló, a flóravidékek, flórajárások elkülönítését szolgáló tanulmányok (lásd Soó Rezső, Borhidi Attila, Csapody István, Jeanplong József, Horvát Adolf, Jávorka Sándor, Kárpáti Zoltán, Pócs Tamás és mások dolgozatait). A határmeghúzásban a szempontok sokáig tisztán florisztikaiak voltak. A kritérium elsősorban a növényföldrajzi kulcsfajok jelenléte volt. Jávorka Sándor felfogásában a flóratájak elkülönülésének vázát a „vezető flóraelemek" elterjedési határai adják (JÁvorKA 1940). Később egyre bevettebb eljárás lett, hogy a Pannonicum tagolása során a flóraadatokat egyes társulások jelenlétének-hiányának figyelembevételével erősítik meg (mint pl. Kárpáti Zoltán a Noricum-Pannonicum határ esetében, KÁRPÁTI 1958, legújabban BorHIDI et al. 2012). Ezt az eljárást Soó Rezső nemcsak alkalmazta, de elvét is magyarázza (Soó 1961). Eszerint a flóraterületek a hierarchia minden fokán egyben vegetációterületek is, ezért a kétféle adatok felcserélhetők. Ezzel a nézettel nem áll egyedül: a flóra- és vegetációtagolás között párhuzamosságot feltételez WALTER és STRAKA (1970) is. Így az euroszibériai térségben az egyes fajok elterjedési típusainak (geoelemeinek) elhatárolását a vegetációtagolás nyomdokán végzik el. E szerint az arktikus flórarégió a tundrarégiónak (zónának), a boreális flórarégió a tajgarégiónak (zónának), a közép-európai flórarégió a lomberdőrégiónak (zónának) felel meg. A kétféle elhatárolás párhuzamosságát durva léptékben jól magyarázza, hogy a nagy vegetációzónák váltása gyakran életformaváltással jár, azok taxonómiai konzekvenciájával együtt. Finomabb térléptéknél ez a párhuzamosság gyengülhet számos tényező okán.

A Pannonicum tagolását szolgáló határmeghúzás máig vegyes szempontokra épül. Valószínűleg így van ez a flóratartomány külső határaival is (Soó 1947). A határmeghúzó eljárások módszertani átláthatatlansága a reprodukálást lehetetlenné teszi. Az egyértelműségnek akkor tennénk eleget, ha a fitogeográfiai rajonírozást tisztán flóra alapra helyeznénk. Kisebb terület, a Gerecse hegység flórakörzeteinek elhatárolásával jó hazai példát nyújtott erre BARINA (2006). Pannonicum-szinten az összes releváns taxon kielégítően pontos elterjedési térképe azonban még nem hozzáférhető. 
3. De milyen flórákkal rokonítható a pannon flóra „egésze”? Soó Rezső a kulcsot a válaszhoz a flóraelemek elemi statisztikájában vélte megtalálni, pontosabban a medence-belső flóraelem-eloszlásában (először: Soó 1940). Az utolsó számbavétel (Pócs 1981) szerint a pannóniai flóra területének nagy részét lefedő magyarországi flórában a keleti, kontinentális (bennük a pontuszi, pontuszipannon) és a déli, szubmediterrán, illetve balkáni elemek fajszám szerinti aránya a teljes fajszámhoz, a pannóniai bennszülött taxonokkal együtt mintegy 33\%. Erre az egyharmadra épül a Pannonicum flóratartomány önállósága. Ezt meghaladja azonban az európai(-középeurópai) és eurázsiai csoportok aránya, összesen körülbelül 45\% (a szubatlanti flóraelemmel együtt). Ezen arányokra épített Soó, amikor a pannóniai flóratartományt az európai flóraterületbe sorolta (Soó 1932, 1945, Soó és Jávorka 1951). A magyar növényföldrajzi irodalom ezt az álláspontot a mai napig magáénak vallja.

Nem mindenki vélekedett azonban így. MEDwECKA-Kornaś (1959) elvetve a közép-európai besorolást, egy közös pontus-pannóniai flóratartomány területét körvonalazza. Hermann Meusel csoportja is keletre tekint, amikor egy pontuszidél-szibériai flórarégióban látja a Pannonicum helyét (MEusel et al. 1965). Ez a nagy kiterjedésű régió a Stipa-sztyeppek és a rétsztyeppek hazája, északi felében (a hegyvidékeken is) erdőssztyepekkel. A Pannonicum nézetük szerint ennek a széles régiónak a legnyugatibb tagja. A medence belsejét Meuselék alföldi altartománynak tekintik, amitől elkülönül a Matricum altartomány. A medence peremének dombés hegyvidéke (a Déli-Kárpátok belső lejtőit is beleértve) tehát a Pannonicum szerves része, amely számos nemzetség (Iris, Cytisus, Onosma, Linum, Colchicum, Dianthus) sztyepp- és erdőssztyeppfaj fejlődési centrumaként működött, gyakran kelet-mediterrán rokonsággal. Meuselék flórabeosztásukkal végül is Kerner nézetét élesztik fel (vö. KERNER 1871). Koncepciójukat mindazonáltal flórastatisztikákkal nem támasztják alá. Figyelemre érdemes, hogy a délkelet-európai vegetáció mélyre hatoló monográfusai (HoRvaT et al. 1974) helyesnek látják Meuselék beosztását.

Egyesek kétségbe vonják a Pannonicum területi egységességét. LAVRENKo (1959) a Pannonicum-ot a közép-európai lomberdőövezethez sorolja, az Alföld kivételével, amely szerinte a pontuszi sztyepp előretolt szigete. WALTER és STRAKA (1970) térképén a közép-európai nemorális övezet délkeleti tartományában sajátos hézag jelentkezik, ez az enklávé a pontuszi-pannon flóraelemek jelenlétével jellemezhető. WALTER és BRECKLE (1986) térképén pedig a Kárpátmedence belső részei a Kárpátoktól elválasztva, exklávészerűen csatlakoznak a két nagy zonobióm, a nemorális és a sztyeppei övezetek zonoökotónjához. Walter flórabeosztását a szárazföldi gerincesek elterjedésével módosítva biogeográfiai térképet közöl Freitag (1962). Ezen nem jelenik meg pannon területi egység, mivel a Kárpát-medencei élővilágot részben (a középhegységekkel) a nagy öszszefüggő közép-európai, részben (a Dunántúl Balatontól délre eső felével) a 
szubmediterrán régióba tagolja, míg a Nagyalföld már a pontuszi flóratartomány szigetszerü exklávéja.

A bemutatott, koncepciójukban eltérő besorolások jól tükrözik térségünk egyedi helyzetét, azt, hogy a különböző irányokból ható flórák hatása alatt áll. Az egyes szerzők szubjektív szempontrendszerük szerint más-más hatás elsődlegességét emelik ki. Meuselék a rájuk jellemző módon a nagy regionális léptékben ismétlődő jelenségeket helyezik előtérbe, emellett befolyásolhatta őket a keleti-kontinentális jellegű társulások jelentős térfoglalása a Kárpát-medencében. Velük szemben Soó tartja magát a (prezencián alapuló) flóraelem-statisztikához. Meuselék - Lavrenko (1959), Freitag (1962) és Walter és Straka (1970) nézetével szemben - hangsúlyozzák az Alföld és a középhegységek flóratartomány-szinten megnyilvánuló egységét (ez Soó alapelve is, Borbási örökség). Ezzel az egységgel mi is egyetértünk, nem úgy az imént felsorolt három munkával.

A besorolások diszharmóniája, a reális látásra való törekvés a teendők sokaságát vetíti előre. Úgy véljük, hogy a flóraelemekre továbbra is építenünk kell, e téren azonban több fejlesztés is kívánatos. Most csak címszavakban: szükség van az egyes flóraelemcsoportok (tipikusan: a legszámosabb csoportot alkotó eurázsiai flóraelemek) finomítására, tovább tagolására, az egyes taxonoknak a mainál pontosabb besorolására. Kívánatos egyfajta súlyozás bevezetése, pontosabban a flóraelem-prezenciák súlyozása, kihasználva a régóta ismert átjárást a vegetációtan és a flórageográfia között. A vegetáció egyes egységeire vonatkozó társulástani táblázatokból ugyanis flóraelem-gyakoriságokhoz juthatunk, ezen gyakoriságok súlyozandók aztán a társulás-állományok térképről leolvasható kiterjedésének arányában (lásd HoRvat et al. 1974). Ezen az úton alakulhat ki a flóraelem gyakoriságok és arányok térségre, térségekre jellemző képe.

\section{A Pannon vegetációrégió}

A florisztikai határmegvonásnak nagyszámú, releváns taxon pontos elterjedési térképén kell alapulnia, ezek lokális áreái azonban nem esnek egybe. Redukálhatjuk a taxonok számát, a kiválasztás azonban növelheti a szubjektivitást. A nyolc országra kiterjedő Pannonicum florisztikai tekintetben nem azonos részletességgel kutatott, ezért a florisztikai határt új lokális flóraművek és modern adatbázisok létrehozásával lenne szükséges kidolgozni. Mindez hosszadalmas, több évre kiterjedő program lehet.

Számos példa tanúsítja, hogy a vegetáció önmagában is alkalmas arra, hogy annak alapján egységes térségeket körülhatároljunk. Alapul gyakran a potenciális vegetáció térképeit használják fel (KüCHLER 1985). A vegetációtérkép elvileg a tér minden pontját minősíti, a térkép felbontásának megfelelő pontossággal. A flóraalapú térképeknél ezzel szemben gyakran hiátussal (nem egyszer teljes adat- 
hiánnyal) kell számolni. A vegetációfoltok többnyire állandóbbak, mint egy-egy taxon előfordulás, és ha egy folt el is tünt, több esély van a rekonstruálásra, mint egy taxon előfordulása esetében.

Térségek vegetációalapú elkülönítésérőlSCHMITHÜSEN (1968) és DIERSCHKE (1994) nyújtanak áttekintést. A magyarul keveset mondó „Vegetationsgebiete” térbelileg szomszédos kisebb területekből állnak össze, közös jellemző társulásokkal. Pontosabban megfogalmazva: a tér vegetációalapú tagolása során keletkező egységeket kiterjedtebb zonális társulások komplexei és kisebb-nagyobb kiterjedésű intra-, extra- és azonális társulások jellemzik. A vegetációalapon megvalósított regionalizáció az Egyesült Államokban, az ún. ökorégió-rendszerekben elterjedt eljárás. Az ökorégió olyan nagy kiterjedésủ, természetföldrajzilag többé-kevésbé egységes terület, ahol a vegetáció hasonló habitatokon kiterjedten és prediktábilis módon jelenik meg (BAILEY 2005). Vegetációalapon áll Kína területének regionalizációja is (ZHANG 2007). Kisebb terület tagolására példa Svájc regionalizálása vegetációtájakra (HEG et al. 1993), de Magyarországon is született ilyen beosztás kisebb tájegységekre (MOLNÁR et al. 2008). Európa növényzetének vegetációalapú (nehezen áttekinthető) tagolására SCHUBERT (idézi DieRsCh Ke 1994) tett kísérletet. SCHMithüSEN (1968) a „Vegetationsgebiete” hierarchikus rendszerére (vegetációrégió, -tartomány, -körzet) is javaslatot tesz (lásd még DierschKe 1994).

A pannon vegetáció térségi tagolását, besorolását a körülhatárolásnak meg kell előznie. Ezt alább mutatjuk be. Akárcsak korábbi dolgozatunkban (FEKETE et al. 2016), itt is a vegetációrégió megnevezéssel élünk, amit széles (semleges) értelemben használunk, tehát nem a hierarchikus rendszer értelmében.

\section{Anyag és módszer}

\section{A Pannon vegetációrégió körülhatárolása}

A Pannon vegetációrégió határának megvonásánál a Kárpát-medence belsejére jellemzö, pannonnak tartott növénytársulásokat, elsősorban a kiterjedt klímazonális és a szintén nagy felületeket fedö, edafikusan meghatározott társulásokat alkalmaztuk. Ezek azok a társulások, amelyek az egyéb, gyakran középeurópai jellegü Carpinus betulus/Fagus sylvatica-uralta erdőket, ill. az ezek zónájában kifejlődött intrazonális társulásokat körbe veszik.

$\mathrm{Az}$ alábbiakban a legfontosabb pannon társulások felsorolását adjuk. Ezeknek - és más társulásoknak - részletes leírását és irodalmát BoRHIDI et al. (2012) munkájában találjuk; alkalmazott társulásneveink is ezt a munkát, esetenként a hivatkozott helyi irodalmat követik. A növényfajok neveit illetően lásd KiráLY (2009), ill. az Euro+Med (2006-2014) adatbázist. 


\section{Pannon vegetációtípusok}

Lösz erdőssztyepp-tölgyesek: a középhegységek Alföldet övező peremein és az Alföld löszvidékein a Quercetum pubescenti-roboris a jellemző zonális erdőtársulás, a szubmediterrán erdőssztyepp domináns képviselője. Az erdőssztyepp fontos fátlan komponense a fajgazdag sztyepprét (pl. Salvio nemorosae-Festucetum rupicolae, Euphorbio pannonicae-Brachypodietum pinnati).

Homoki erdőssztyepp-tölgyesek: a kiterjedt homokvidékek erdei a félszáraz és száraz homoki tölgyesek, a Kárpát-medence unikális társulásai. A zártabb lombkoronájú (Convallario- és Polygonato latifolii-Quercetum roboris, Festuco rupicolae- és Iridi variegatae-Quercetum roboris). A legszárazabb homokterületek potenciális fás társulása a Junipero-Populetum albae.

Nyílt homoki gyepek: nagymértékben unikális a legszárazabb, meszes homokon a nyílt homokpusztagyep, a Festucetum vaginatae, Stipa borysthenica-val, helyenként Festuca wagneri-vel. Ebben a társulásban a legnagyobb a pannóniai bennszülöttek fajszáma (elsősorban a Duna-Tisza köze homokján). Endemikus a nyírségi mészkerülő homokpusztagyep (Festuco vaginatae-Corynephoretum) is.

Szikesek: Magyarország egyik legkiterjedtebb gyeptípusát a szikes gyepek (pl. Artemisiosantonici-Festucetumpseudovinae, Agrostiostoloniferae-Alopecuretum pratensis, Lepidio crassifoliae-Camphorosmetum annuae, Puccinellietum limosae) jelentik. A pannon szikes a fajok eredete és a talajfolyamatok dinamikája miatt is lényegesen különbözik a tengerparti sós társulásoktól. A különállást a pannóniai endemizmusok nagy száma is erősíti, a jellemző fajok többsége pontusi-pannon, illetve gyakran irano-turáni elterjedésü.

Sziki tölgyesek: Európában máshonnan csaknem ismeretlen a sziki tölgyes (Galatello-Quercetum roboris). Mozaikos szerkezetü erdőssztyepp-erdő, a tisztásain fellépő Peucedano-Asteretum sedifolii egy kontinentális magaskórós vegetációtípus képviselöje.

Keményfás ártéri erdők: a folyók széles magasárterén a Fraxino pannonicaeUlmetum és rokonai a potenciális erdőtársulások. Pannon jellegüket elsősorban a Fraxinus angustifolia subsp. danubialis adja.

Cseres-kocsánytalan tölgyesek: Quercus petraea-Quercus cerris erdők. A pannon tájban a dombvidékek és alacsony hegyvidékek legnagyobb térfoglalású zonális társulása a Quercetum petraeae-cerridis. Ez egyben Magyarország legnagyobb kiterjedésű potenciális vegetációtípusa is (JAKUCS 1985). Mivel a Pannon vegetációrégió lehatárolásakor e társulásnak kiemelt szerepe volt, részletesebben jellemezzük. A Quercus cerris klímaindikátor, Kárpát-medencei elterjedésének északi határa (FEKETE és BlatTNy 1913) jól illeszkedik az ún. Moesz-vonalhoz (Moesz 1911). A Moesz-vonal a pannóniai fajok elterjedésének és egyben a szőlő termesztésének északi határa. A Quercetum petraeae-cerridis konstans fajai zömmel déli, 
szubmediterrán, pannon-balkán és szubmediterrán-közép-európai fajok, ezek a pannon flóra inherens komponensei. A Quercus cerris kelet-szubmediterrán elterjedésü, a társulás másik domináns faja, a Quercus petraea, jobbára Közép-Európához kötődik, a Pannonicum-ban egy közös társulást alkotva érik el a közel optimális növekedést. Kodominanciájuk jól mutatja a pannon régió átmeneti jellegét. A florisztikai kompozíció alapján is átmeneti a társulás a szarmata Potentillo albae-Quercetum roboris és az északi-kelet-balkáni Quercetum farnetto-cerridis között (Soó 1963). A Quercetum petraeae-cerridis önálló pannon társulás, előbbiektől jól elválik. A potenciális növényzetben közvetlenül csatlakozhatnak az Quercetum pubescenti-roboris erdőssztyepp-erdőkhöz, ilyen állományaikban Aceri-Quercion fajok (pl. Aconitum anthora, Doronicum hungaricum, Pulmonaria mollissima, Waldsteinia geoides) jelennek meg (Kovács és PoDANi 1979). Ezen túl is számos dél- és délkelet-európai, kontinentális és pannon-balkáni fajuk közös lehet (Kovács 1975). A Quercetum petraeae-cerridis fényben gazdag gyepszintjében rendszeresen megjelenhetnek Festuco-Brometea-fajok (lásd Kovács és Podani 1979). Az Asphodelo-Quercetum roboris társulást (BORHIDI és JÁRAI-KOMLódi 1959, TALLÓs 1959, KEVEY 2011) a cönológiai osztályozással szemben (BoRHIDI et al. 2012) inkább pannon, mint illírnek jellegünek tekintjük. Az alkalmanként fellépő szubmediterrán, szubatlantiszubmediterrán, illír fajok (Asphodelus albus, Primula vulgaris, Luzula forsteri, Tamus communis, Knautia drymeia) mellett több tucat faja a zonális pannon cserestölgyessel közös. A homokon, olykor kavicson megjelenő erdő klímazonálisnak tekinthető (Quercus petraea-val, TALlós 1959), lásd még MAJER 1980, Kevey 2008, BORHIDI et al. 2012). Hasonlít hozzá, de illír jelleget már egyáltalán nem mutat az Agrostio tenuis-Quercetum cerridis társulás (CSAPODY 1974, KeVEy 2008, Király és KIRÁLY 2008). Mindkét társulásnak erdőssztyepp jellege is van (BorHIDI és JÁrAi-Komlódi 1959, KeVEy 2011, lásd még Zólyomi 1941). A Quercus robur túlsúlya mindkét esetben edafikus meghatározottságot jelez.

A Quercetum petraeae-cerridis öv pannon jellegét az állományai által körülölelt hegységek egyes magassági öveiben intrazonálisan megjelenő, edafikusan meghatározott, bennszülött társulások erősítik. Legnagyobb kiterjedést talán a molyhos tölgyes bokorerdők érik el (Cotino-Quercetum pubescentis, Ceraso mahaleb-Quercetum pubescentis) elsősorban dolomiton, mészkövön, száraz, meleg lejtőkön. Jellemzőjük a mozaikos, gyepekkel váltakozó szerkezet, a letörpülő Quercus pubescens és Fraxinus ornus, valamint a kétsziküekben gazdag szegély. A fajkészlet kettős jellege (lásd feljebb) pannon jellegzetesség (FeKETE et al. $2011,2014)$. Erös pannon jellegeket hordoz a dolomitsziklagyep is (Seseleo leucospermi-Festucetum pallentis), több pannon endemizmus kizárólagos élőhelye. További, kisebb állományokban megjelenő pannon társulások többek között a Waldsteinio-Spiraeetum mediae, a Tilio-Fraxinetum excelsioris, a Poetum scabrae és a Campanulo macrostachyae-Stipetum tirsae. 
Az adatok forrása

A Pannon vegetációrégió határvonalának meghúzásához terepi tapasztalataink mellett potenciális vegetációtérképeket és helyi vegetációleírásokat használtunk:

1) Magyarország természetes növénytakarójának 1: 1500000 méretarányú térképe (Zólyomi 1967, 1989), ill. a határövezetet tárgyaló további dolgozatok (Zólyomi 1941, JeAn Plong 1956, Pócs 1960);

2) Csehszlovákia természetes potenciális vegetációjának 1: 200000 méretarányú térképe (Szlovákia: MichAL ko et al. 1984-1986, Csehország: Mi KYšKA et al. 1968-1972), valamint a kapcsolódó szöveges magyarázó (MICHAL Ko et al. 1987), ill. Szlovákia korábbi, 1: 500000 méretarányú áttekintő térképe (MICHALKo et al. 1979);

3) Jugoszlávia természetes, potenciális növényzetének 1: 1000000 arányú térképe és vegetációleírása (FUKAREK és JovANOVIĆ 1986);

4) Románia potenciális vegetációtérképe (IvAN et al. 1993);

5) a dunai országok természetes vegetációjának térképe (1: 2000 000, NiKLFELD 1974);

6) Európa 1:2500 000 méretarányú potenciális vegetációtérképe (BOHN et al. 2000);

7) Magyarország aktuális élőhely-térképezési adatbázisából származtatott elterjedési térképek (MOLNÁR et al. 2008, BöLöNI et al. 2008), valamint élőhelyjellemzések (BöLÖNI et al. 2011), Magyarország földrajzi kistájainak florisztikai és vegetációs jellemzései (KIRÁLY et al. 2008);

8) vegetációleírások, társulástani táblázatok a régió pereméről (lásd az irodalomjegyzéket).

\section{A körülhatárolás módszere}

A Pannon vegetációrégió határvonalát Európa potenciális vegetációtérképére (BOHN et al. 2000), mint közös platformra húztuk be. Kezdetként egy ideiglenes vonalat húztunk e térképen azonosítható pannon társulások külső határa mentén. Ezt a vonalat finomítottuk ezután nagyobb felbontású vegetációtérképek, leírások, olykor pedig saját tereptapasztalat alapján. Azok a tájak tartoztak a Pannon vegetációrégióhoz, amelyek növényzete dominánsan pannon jellegü (a pannon társulások borítása nagyobb, mint 50\%), illetve a nem-pannon (pl. Fagetalia) társulások felszínborítása elhanyagolható volt. A határt legtöbb esetben valamilyen pannon társulás, társulásmozaik külső határán, többnyire a Quercetum petraeae-cerridis és a Carpinus betulus/Fagus sylvatica-uralta erdők között húztuk meg. Ha egy pannon jellegű társulás, társulásmozaik teljesen körülölelt más, többnyire Carpinus betulus/Fagus sylvatica-uralta tájakat (jellemzően szi- 
getszerü hegy- és dombvidékeket), azokat a pannon régió részének tekintettük. A nem pannon jellegű vegetáció zárványszerű megjelenését nem határoltuk le.

Ha azonális ártéri növényzet volt a két szomszédos vegetációrégió közötti részen, akkor önkényesen a folyók mai vonalában húztuk meg a határt. Ha a pannon vegetációval borított tájakat régiójellegzetességeket nem mutató, de nem ártéri tájak határolták, akkor ezeknek a pannon régió felé eső oldalán húztuk meg a határt. A határszakaszok mindkét oldalán megadtuk a jellemző növénytársulások nevét. A szomszédos vegetációrégiókat nem jellemeztük, ezeket önálló kritériumok alapján kell majd meghatározni.

\section{Eredmények}

\section{Az északi, északnyugati határvonal}

A Pannon vegetációrégió határát lásd az 1. ábrán. A határvonalat északról indulva mutatjuk be.

A Kisalföld, ill. a Duna-menti síkság és a tőle északra fekvő löszvidék egykor kiterjedt erdőssztyepp-tölgyeseit (Quercetum pubescentis-roboris, vö. HoRvÁTHGoDÁNy 1977) északabbra a Quercetum petraeae-cerridis váltja fel, ezek képezik itt a pannon régió határát. Tőlük még északabbra a tölgyeseket már a rokon Potentillo albae-Quercetum roboris képviseli (BoHN et al. 2000, RoLEČEK 2005). A Vág völgyében, illetőleg a Fehér-Kárpátok és a Kis-Kárpátok találkozásánál a szubmediterrán jellegü Cotino-Quercetum pubescentis képviseli a pannon vegetációt (Futák 1947, JAKUCS 1961, MiCHAL Ko et al. 1987, CHYTRÝ 1994), másutt - ugyancsak mikroklimatikus-edafikus hatásokra - a már inkább kontinentális jellegü melegkedvelő tölgyesek (Corno-Quercetum pubescentis, ROLEČEK 2005). Ezek a xerotherm erdők nem fordulnak elő lényegesen északabbra, mint a zonális xeromezofil, zárt tölgyesek. Az Ondava völgyében a Quercetum pubescenti-roboris képezi a határ belső oldalát. Északabbra már csak apróbb pannon vegetációfragmentumok mutathatóak ki, pl. a karszbokorerdő fragmentumai a Vihorláton (JAKUCS 1961). Az Északnyugati- és Északi-Kárpátok felől a határ északi oldalát csaknem teljes hosszában a Carici pilosae-Carpinetum, kivételesen a rokon TilioCarpinetum adja (Michal Ko et al. 1984-86).

Nyugatabbra, Morvaország délkeleti részét egykor gazdag pannon vegetáció fedte. E régió határát nyugat felé főleg a sztyeppfoltokkal mozaikoló Quercetum pubescenti-roboris erdők jelölik ki (CHYTRÝ és HoRÁK 1997). Morvaország pannon részén (vö. KAPLAN 2012) egy, a magyarországi erdőssztyepp-tölgyesekhez közelálló, endemikusnak értékelt társulást is leírtak (Carici fritschii-Quercetum roboris, CHYTRÝ és HorÁx 1997). Jelentős kiterjedést érnek el a Inulo hirtae-Stipetum tirsae erdőssztyepprétek (DUBRAVkovÁ et al. 2010). Egykor azonális pannon növényzet, 
pl. Thero-Salicornietea-társulások is előfordultak, de mára ezek erősen degradálódtak, vagy már el is tűntek (СHYTRÝ 2012). Löszön, sekély lejtésủ felszíneken ismeretes a Quercetum petraeae-cerridis Quercus cerris nélküli változata (CHYTRÝ és HoRÁK 1997). Vegetációrégiónk morvaországi határszakaszának vonala nagyjából a CHYTRÝ (2012) közölte vonalat követi. Az ún. pannon (szubpannon) Quercus robur-Carpinus betulus erdők elterjedtek Szlovákia, Ausztria és Morvaország meleg, szubkontinentális részeinek síkságain és a dombok közötti széles völgyekben (Michalko et al. 1987, Mucina et al. 1993). Ezek az erdők (Primulo verisQuercetum roboris, Polygonato latifoliae-Carpinetum) mind az erdőssztyepp, mind a zárt tölgyes zónára jellemzőek, külső határaikon túl alig találhatóak.

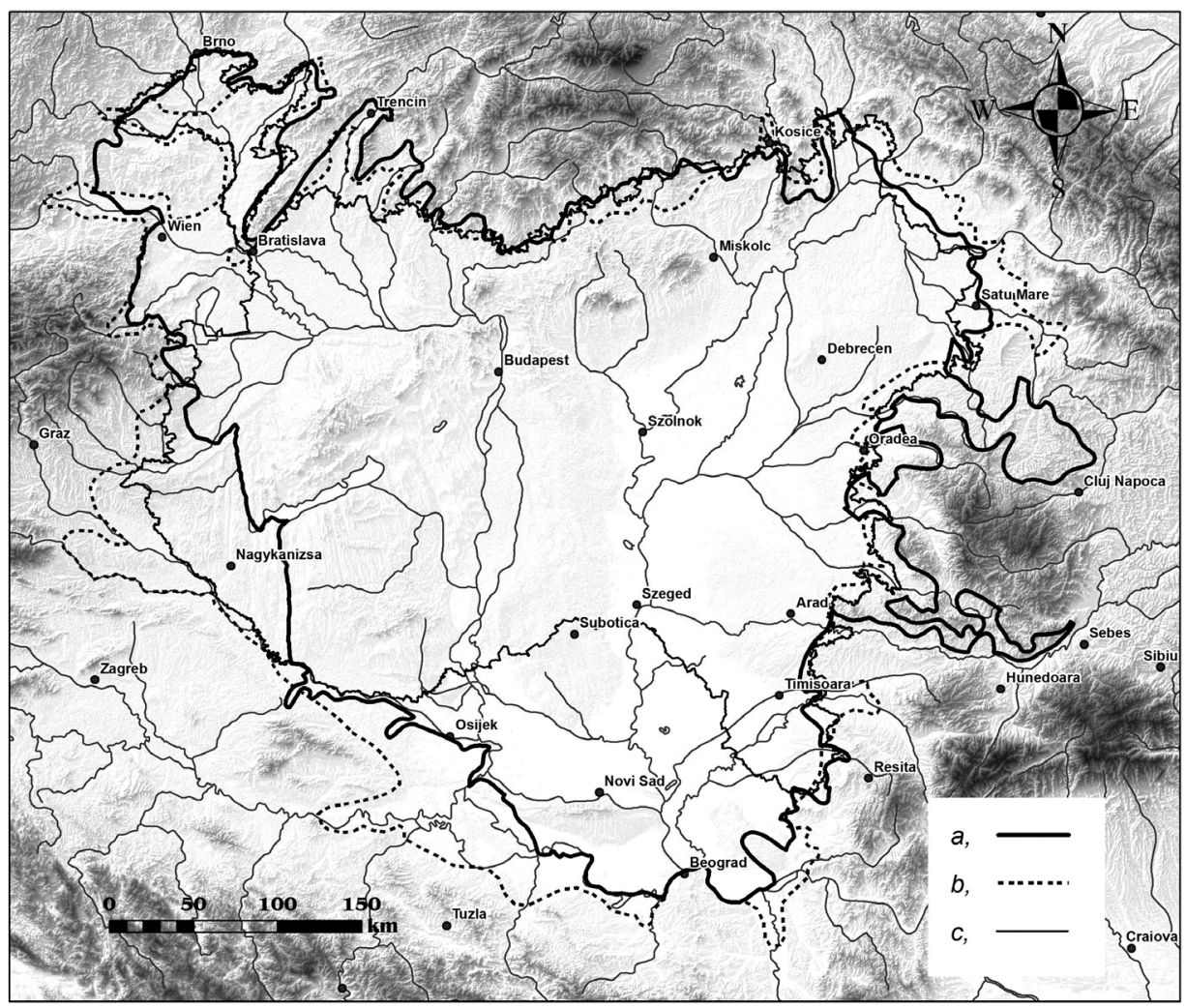

1. ábra. a) a Pannon vegetációrégió határa; b) a Pannonicum flórarégió legfrissebb határa (Soó 1947); és c) az európai uniós Pannon biogeográfiai régió határa (Natura 2000, ANON. 2014, megj.: többször országhatárokon halad) (alaptérkép forrása: ASTER-GDEM, 2009, NASA).

Fig. 1. The boundary lines of the a) Pannonian vegetation region; b) the Pannonicum floristic region based on latest version covering the whole region (Soó 1947); and c) the Pannonian biogeographic region of the European Union (Natura 2000, ANON. 2014, note: it often runs on country borders) (source of base map: ASTER-GDEM, 2009, NASA). 
Délkelet-Morvaország pannon vegetációja folytatódik Alsó-Ausztriában, a Morvamezőn, a Bécsi-medencében, Észak-Burgenlandban is (vö. NikLFELD 1993, KILIAN et al. 1994, WiLlnER 2013). A potenciális vegetációban pannon társulásokban gazdag az alföldi vegetáció (halofiton társulásokkal, homokpusztákkal, lösznövényzettel, illetve a löszfalak pionír félsivatagi együttesével (HÜBL és Holzner 1975). Sík vidéken a klímazonális potenciális vegetációban a Quercetum pubescenti-roboris, az alacsony dombvidékeken a Quercetum petraeae-cerridis az uralkodó (GEerdes és Moll 1983, KarRer és KiliaN 1990, WALlNÖFER 2003). Az utóbbi társulás öve gazdag intrazonális pannon társulásokban (bazofil sziklai vegetáció: NiKLFELD 1964), xerotherm tölgyesek: Ceraso-Quercetum pubescentis és Corno-Quercetum pubescentis (KARRER és KILIAN 1990, WALLNÖFER 2003). Alsó-Ausztriában nyugat felől a határt középeurópai Carpinus betulus/Fagus sylvatica-uralta erdők (pl. Carici pilosae-Carpinetum és Primulo veris-Carpinetum) képezik, olykor a hercyniai Potentillo albaeQuercetum roboris. Ugyanitt a szarmata és a pannon tölgyesek átmeneti állományokat is alkothatnak (HüBL és HolzNER 1975, vö. még HoRvát 1980, 1981, Geerdes és Moll 1983, Mucina et al. 1993).

\section{A nyugati határvonal}

A Lajta-hegységtől délre a határ a Soproni-hegység keleti peremén húzódik, majd (visszakanyarodva Ausztriába) pannon jellegűek Burgenland középső dombvidékei is. Délkeletre a határt a dombvidékeken (Répce- és Gyöngyös-sík, Kemeneshát) Cyclamini-Carpinetum képezi (Zólyomi 1967, 1989). E határ keleti oldalán az egyértelmüen pannon jellegü cseres-tölgyesek mellett az Agrostio tenuis-Quercetum cerridis (Répce-sík, Kemeneshát, CsAPODY 1974) is megjelenik, ill. a Somogy és Zala felől felhúzódó Asphodelo-Quercetum roboris (BORHIDI és JÁrAi-Komlódi 1959, Kevey 2011) is, lokális, edafikus okokból. A nyugat felől határoló Kelet-zalai dombságon már Fagetalia-társulások dominálnak. A Balaton vonalát (Keszthely térségében) elérve a Zala árterének ligeterdei, mocsarai mentén halad a határ. Somogy megye nyugati részén az illír Carpinion és Aremonio-Fagion, illetve a pannon Asphodelo-Quercetum állományok átmeneti sávjának középvonala képezi a határt egészen a Dráváig.

\section{A déli határvonal}

A Dunántúl délkeleti szélén a Dráva az önkényesen kijelölt határ. A dunai szakaszon az erdőssztyepp-erdők fellazulnak, bennük számos sztyeppelem jelenik meg akárcsak az északabbi Vajdaságban (Jovanović 1997, PURGER et al. 2014). A Fruška Gora xerikus-mezoxerikus Quercetum cerridis-virgilianae társulása Jovanović (1997) szerint az erdőssztyepp-erdők képviselője (de lásd 
PURGer et al. 2014). A Drinától keletnek a határt dél felől a Genisto-Quercetum roboris erdők jelölik ki, másutt pedig a dél felől felhatoló illír-nyugat-mőziai Quercus farnetto-Quercus cerris erdők (Jovanović et al. 1986). Összehasonlítva az északi és az északnyugati határszakaszokkal, lényeges különbség itt a pannon Quercetum petraeae-cerridis hiánya.

\section{A keleti határvonal}

A Nyugat-romániai-síkságot kelet felé szegélyező dombvidéket és hegylábakat Quercus farnetto és Q. cerris erdők borítják. A Bánátban és északabbra, a Maros völgyétől délre elhúzódó dombvidéken kiterjedt erdők a Kelet-Balkánról felhúzódó Quercus farnetto-n kívül alig különböznek a táj többi zonális tölgyesétől. Balkáni fajokban való szegénységükkel viszont elütnek egyéb területek Quercus farnetto erdőitől (Jovanović 1997). Fajkészletük részben a szomszédos alföldi zóna Quercetum pubescenti-roboris erdőivel rokon, részben pedig a magasabb dombvidékek Quercetum petraeae-cerridis erdeihez hasonló. Jobbára hiányoznak belöle a xeromezofil-mezofil, de főleg a mezofil fajok, uralkodnak a száraz tölgyes- és erdőssztyepp-fajok, amelyek jórészt kontinentális elterjedésűek, mint a konstans Acer tataricum. Az erdő szegélyében gyakran Trifolio-Geranietea társulások jelennek meg (ColdEA és Pop 1996). A Maros és a Sebes-Körös közötti térségben egy síksági variáns (Quercetum farnetto-cerridis crisicum, POP 1967) alakult ki. Ezen magyar tölgy-csertölgy erdők kontinentális jellegét a klíma okozza: az erős téli hideg, a nagy hőmérsékletingadozás és a kifejezett nyári száraz periódus (HoRvat et al. 1974). E klíma közel áll a szomszédos Alföld erdőssztyeppklímájához. A kodomináns magyar tölgy jelenléte miatt ezen erdőt mégsem a pannon vegetáció részének, hanem a balkáni vegetáció szélső képviselőjének tekintjük; ezek az erdők határolják kelet felől számos ponton a pannon régiót.

A Bánátban, az Erdélyi-szigethegység nyugati peremén, a Szamos-menti dombokon, valamint a Maros-völgyben egészen az Erdélyi-Mezőségig a Quercetum farnetto-cerridis zónával Quercetum petraeae-cerridis erdők határosak (PoP et al. 1978, CsŰRÖs 1981, ARDELEAN 1999). A társulás fajkompozíciója a magyarországi dombvidékek Quercetum petraeae-cerridis erdeihez hasonló. Ezen erdők benyomulása az Erdélyi-medencébe az Erdélyi-szigethegység délkeleti esőárnyékában jó megegyezésben van az itt (Gyulafehérvár) kimutatott három hónapos szemiarid-szemihumid klímaperiódussal (KUN et al. 2004), amely az Erdélyi-medencében egyedülálló. A Tasnádi-dombvidék egyik leggyakoribb erdeje szintén a Quercetum petraeae-cerridis, e társulás 200 és $350 \mathrm{~m}$ tfsz. magasságokban zonális (KARÁCsONYI 2010, 2011). Így végül is a régió keleti határát a kocsánytalan tölgy-csertölgy erdők keleti határa mentén húztuk meg. Ez a határ lényegesen eltér a korábban (Soó 1947) meghúzott flórahatártól. 
A Pannon vegetációrégiót a külső oldalról az Erdélyi-szigethegység peremén mezofil lomberdők, a Szamos-menti dombokon Quercus robur erdők, ill. Carpinus betulus/Fagus sylvatica-uralta társulások határolják. A Maros-völgytől délre már tölgyesek jellemzik a határ külső oldalát (Quercus petraea, sőt: Carpinus orientalis erdők, BoHN et al. 2000).

Északkeleten, az ukrán-magyar határ körzetében a Pannon vegetációrégió határát az ártéri terület közepén a Tisza és Bodrog folyók vonalán, azaz önkényes vonalon húztuk meg. E tájban és tőle keletre csak kis kiterjedésben található pannon vegetáció, pl. egy keskeny xeromezofil tölgyes sáv a hegyek peremén (NikLFELD 1974, leírásukat lásd DiDUKH et al. 2011) és a síkságból kiemelkedő száraz dombokon és előhegyeken (FoDOR 1960).

\section{Megvitatás}

A Pannon vegetációrégió határa zömmel a Magyar Alföldet övező hegyés dombvidékeken fut körbe, ritkán folyóárterek alkotják a határt. A határon kívül számottevő kiterjedésű pannon társulásállományok nem fordulnak elő. Zárványnak fogadtuk el az Északi-középhegység Carici pilosae-Carpinetum és Melittio-Fagetum uralta tájait (pl. Börzsöny, Bükk, Mátra), ill. délen a Mecseket és a Zselicet, valamint a Fruška Gora-t. A leghosszabb határszakaszok (ÉszakiKárpátok, Alsó-Ausztria, Erdély) a Quercetum petraeae-cerridis társulás elterjedési határa mentén találhatók.

A vegetációgeográfiai határ sokszor meglepően éles, különösen ott, ahol a domborzati váltás éles (síkság-dombvidék), és ez még hirtelen alapkőzetváltással is párosul. Nagyobb magasságoknál a pannon tölgyeseket Carpinus/Fagus-uralta erdők váltják. A határ élességének oka ilyenkor az, hogy a mezofil gyertyánostölgyes záródása miatti fényszegény környezete hátrányos a fénykedvelö tölgyes zóna fajainak, ugyanakkor kedvez a hegyvidéki kötődésű flórának. A határ léptéke helyenként csupán néhány tíz méter („limes convergens”, DiersCH KE 1994). A florisztikai határvonalak gyakran sokkal szélesebbek. A Soproni-hegység területén a Pannonicum és Noricum határán markáns határvonal helyett „florisztikai lépcsők" sora figyelhető meg egy 2-3 km sávban (KIRÁly és SZMORAD 2004). Hasonlóan, a Pannonicum és a Hercynicum határán egy 1-2 km széles átmeneti sávot dokumentáltak. Ebben az átmeneti sávban számos, a Hercynicum-mal, ill. a Pannonicum-mal közös taxon jelenik meg, de egyedi jellemvonásokat is hordoz, számos faj csak itt jelenik meg (Chytrú et al. 1999). A Pannonicum és a Dacicum határán fekvő Szilágyság dombvidékén különösen széles az átmenet. Pannon, pontus-pannon és pontus-szubmediterrán fajok grádiense figyelhető meg az Erdélyi-Mezőség felé (KARÁcsONYi és NEGREAN 2014). 
Vegetációrégiók közötti területek átmeneti vagy jellegtelen növényzettel

A pannon és az alpesi régió közötti kiterjedt dombvidék uralkodó vegetációja átmenetinek mondható. Benne a két szomszédos régió hatása is érvényesül, de emellett még a Nyugat-Balkáné is, főleg a Carpinus-Quercus, valamint a Fagus-erdőkben (Pócs 1960). E terület jellegét erdeifenyő-lombelegyes erdők (Genisto nervataePinetum sylvestris) is meghatározzák, ritka fajokat rejtegető lápi, mocsári társulásokkal. Ezek az egykor összefüggő boreális erdőzóna képviselői, a posztglaciális erdőfejlődés korai szakaszának reliktumai. A vegetációtípusoknak ez a sajátos elegye, a terület átmeneti jellege végül is annak egyediségéhez vezet, mivel erősen különbözik mindkét szomszédos régiótól. Hogy a vegetáción alapuló ún. ökorégiók közötti átmeneti zónák meglehetősen szélesek lehetnek, arra BAILEY (2005) hoz fel példákat (lásd még KüCHLER 1973). Az átmeneti vegetációtájakkal analóg jelenség a földrajzi tájaknál - amelyeknek éppen a vegetáció az egyik erős attribútuma - is megfigyelhető: közöttük rendesen átmenetek alakulnak ki (KÁDÁR 1965). Általánosabban: a biogeográfiai régiók egyes szakaszokon éles határokat formálnak, más szakaszokon viszont széles átmenetű zónákat (OLIVIERo et al. 2013).

Érdekes problémát jelent a WRABER (1969) által körülhatárolt ún. szubpannon terület Szlovéniában, föleg Querco-Carpinetum klímax-szal. Kétségtelen, hogy az ún. „Goričko” dombvidékén az illír elemek - valószínüleg edafikus okokból - csaknem teljesen hiányoznak. A szubpannon területen azonban pannon társulások jelenlétéről nem tesz említést. Fukarek már az egész illír flóratartomány határait vizsgálja és ennek vonatkozó szakaszát a Dinári-hegységet északkeleten övező dombvidék peremére helyezi (FUKAREK 1977, 1979). Fukarek Wrabernél tovább megy, mivel e vonal és a Száva közötti területet, továbbá a Szávától északra fekvő térséget is a pannon flóratartomány részének tartja. MARINČEK (1995) az illír határt északabbra helyezi, mint Fukarek, de a Szávától északra fekvő terület már szerinte is a Pannon flóratartomány része. Véleményét azonban a Dráva és a Száva közötti hosszú, horvát szakaszon pannon társulások jelenlétével ő sem támasztja alá. Kelet-Szlavónia síksági erdői ugyan helyenként Quercus cerris-ben gazdagok, ezek azonban nem Quercetum petraeae-cerridis erdők (FRANJIC et al. 2005). A fenti javaslatokat a pannon flórageográfiai/vegetációgeográfiai régió ilyen jellegü kiterjesztésére nem fogadhatjuk el. Nyilvánvaló, hogy az említett délszláv kutatók a pannon jelleget relativizálták, nem téve magukévá az elvet, miszerint minden régiót annak saját kritériumrendszere alapján kell elhatárolni. Amúgy a lehatároláshoz flóra- és vegetációgeográfiai érveket egyaránt használtak, ami a tisztánlátást megnehezíti. Úgy véljük, számolnunk kell azzal, hogy a biogeográfiai régiók között léteznek jellegtelen, átmeneti területek, ezeket nehéz vagy éppen lehetetlen bármely növényföldrajzi régióhoz besorolni - jó példa erre a tárgyalt Dráva és a Száva közötti terület. 


\section{A flóra- és vegetációhatárok egybeesése}

Úgy találtuk, hogy a Pannonicum és a Pannon vegetációrégió határai nem esnek teljesen egybe. Az eltéréseknek többféle oka is lehet. Triviális ok, hogy a flórarégiók lehatárolása figyelembe veheti azon fajelőfordulásokat, amelyek extrazonális pannon társulásfoltokhoz kötődnek, a zonális társulások vonalán kívül. Egyes populációk itt elszigetelten, pl. mint társulásreliktumok is megjelenhetnek. Az eltérés mértéke erősen változó, ahol egy egyenletes környezeti grádiens alakul ki, ott az egybeesés kifejezett. Ez a helyzet északon, ahol a pannon flóra határát a kárpáti felé már MoEsz (1911) tanulmányozta. Ezt a határvonalat később több faj alapján is meghúzták (FUTÁK 1966). Futák flóravonala és a vegetációrégió határvonala (amit MICHAL Ko 1984-1986 térképe alapján ismerünk) jó megegyezésben vannak egymással (kivételt képez a Szlovák Karszt). A nagy hasonlóság oka az lehet, hogy a Kárpátok felé a magassági grádiens viszonylag egyenletes, és ezért viszonylag egyértelmű a Quercetum petraeae-cerridis és a szomszédos Carpinus betulus-uralta erdők határa.

Más esetekben a két határ távolabb esik egymástól. Nyugat-Magyarországon a vegetációgeográfiai határ a flórahatártól 10-60 km-rel keletebbre húzódik. Ezt a területet - amelyet a nyugat-dunántúli flóravidék fed (JÁvorKA 1924-25, GÁYer 1925, Soó 1933, KÁRPÁti 1958, 1960, lásd még Pócs 1981 térképét), fentebb jellemeztük. Klímazonális pannon társulások itt nem találhatóak, legfeljebb a Quercetum petraeae-cerridis néhány, többnyire extrazonális állománya, illetve egyéb társulásfragmentumok (a Kőszegi- és Soproni-hegység, valamint a Vas-hegy xerotherm élőhelyei, a Zalai-dombság xeromezofil gyepjei; vö. Koó 1994, Szmorad 1994, Király et al. 1999, Király és Szmorad 2004). A pannon endemizmusok itt ritkák: $0-1 \mathrm{faj} / 140 \mathrm{~km}^{2}$, szemben a Kárpát-medence középső területén várható 3-10(-15) fajjal (BARTHA et al. 2015). Ezért MEUSEL et al. (1965) nem is tekinti e területet a Pannonicum részének, hanem egy köztes, átmeneti flórájú egységnek (flóra-altartomány), amely Nyugat- és DélnyugatMagyarországra, részben Burgenlandra, Dél-Stájerországra és Észak-Szlovéniára terjed ki. Ez az altartomány egyaránt elkülönül az Alpicumtól, a Pannonicumtól és az Illyricumtól. Jelezzük, hogy az altartomány északi határa közel esik a Pannon vegetációrégió határához. Bár nem ismerjük közelről Meuselék szempontjait a határ meghúzásához, javasoljuk, hogy a Pannonicum e szakaszának jelenlegi határát a kontinentális, pontuszi, pontuszi-pannon, pontuszi-szubmediterrán és a xerofil szubmediterrán fajok elterjedésének figyelembevételével korrigálják majd. Várható, hogy ekkor a jelenleg elfogadott florisztikai határ (Soó 1947, Pócs 1981) közelebb kerül a vegetáció-alapú határhoz.

Jelenleg nagy a diszkrepancia a florisztikai, illetve a vegetációs határ között a pannon térség keleti szélein. Várakozásunk szerint a térségben folyó intenzív florisztikai kutatások új, finomított határhoz vezetnek majd. 


\section{Pannon vegetáció, európai vegetáció}

A Pannon vegetációrégió helyének kijelölése egy világosan felépített, a nagy kiterjedésű társulások hasonlóságára, rokonságára épülő, hierarchikus európai rendszerben célszerűnek tűnik. Ilyenhez jó topográfiai alapot és kiindulást nyújt a nagy erőfeszítéssel létrehozott, 1: 2500000 léptékű európai vegetációtérkép, illetve annak fontos változata, az 1: 10000000 léptékü áttekintő térkép (BOHN et al. 2000), amely az eredeti térkép rokon tartalmú foltjainak összevonása révén állt elő. Knapp ezen utóbbi térképre építve kísérelte meg a vegetáció kisebbnagyobb rangú térbeli egységeiknek a körülhatárolását (KNAPP 2005). Knapp megoldása, noha még nem általánosan elfogadott, egyszerü és általában ésszerü. SCHMITHÜSEN (1968) hierarchikus rendszerét alkalmazza (lásd fentebb), ebben a pannon vegetációterület értelem szerint a vegetációkörzet kategóriának felel meg.

BoHN et al. (2000) áttekintő térképén jól követhető a szubmediterrán száraz tölgyesek határa is, a kontinens teljes szélességében. KNAPP szerint ezen, régiónak tekintett öv keleti része a kelet-szubmediterrán elegyes tölgyesek tartománya. Ezen belül helyezkedik el a balkáni tölgyes vegetációkörzet, amelyet északabbra a pannon-erdélyi elegyes tölgyes-körzet követ, mint a vegetációtartomány lezárása. KNAPP szerint azonban a Kárpát-medencében egy másik tartomány, a pontuszi-pannon erdőssztyepp-tartomány képviseletében (egy elszigetelt folt formájában) a pannon erdőssztyepp-körzet is megjelenik.

A Kárpát-medencében az erdőssztyepp-növényzet azonban nem egyetlen elszigetelt folt. A medencebelső keleti határától az észak-nyugatiig végigvonulva megjelenik, egy nagy központi tömb (Nagyalföld) mellett nyugat felé szakadozottan, gyakran egymástól elkülönült foltok formájában a szubmediterrán jellegeket hordozó pannon vegetáció, a zárt tölgyesek által kijelölt határáig. Helyenként összefonódnak az ilyen tölgyesek foltjaival, másutt emezek körbezárják az erdőssztyepp-foltokat. A keleti végen az Erdélyi-medence erdőssztyepp-erdői és a Mezőség pusztái teljesen elkülönülten jelentkeznek a Nagyalföldtől, a szubmediterrán jelleg szinte eltűnik, egyértelműen dominál a hüvös-kontinentális jelleg (fajokban, erdő-gyep mintázatokban, pl. a kettő határának élességében). Ezért az erdőssztyepp-vegetációt a Kárpát-medencében összefüggő területi egységként ábrázolni, felfogni - mint azt KNAPP (2005) teszi - nem lehet (lásd pl. A Kárpát-medence és környéke potenciális erdőssztyepp területei c. ábrát, in Molnár és Kun 2000, p. 12).

A kétféle vegetáció (zárt tölgyes, ill. erdőssztyepp) foltjainak egymásmellettiségéből fakadó ráhatásnak tág tere van és főleg volt a posztglaciális vegetációmozgások során, mint azt néhány pannóniai példa is mutatja. Az erdőssztyepp zonális erdői és sztyepptársulásai a dombságok, alacsony hegyvidékek vegetációjával (amit a cseres-tölgyesek uralnak) széles fronton érintkeznek. A kétféle vegetáció összefonódására számos példa ismeretes: 
- Az alföldi löszerdők: klímazonális erdőssztepp-erdeink különösen a Kelet-Dunántúlon szoros rokonságban állnak hegyvidékeink mészkedvelő tölgyeseivel, határhelyzetben csaknem elkülöníthetetlenek tőlük. Ezért vezették be a szubmediterrán erdőssztyepp fogalmát.

- Erdőssztyepp-erdők (Corno-Quercetum pubescentis, melegkedvelő tölgyesek) hegyvidékeken, a zárt tölgyesek területén is kialakulnak.

- A legfajgazdagabb sztyepprétek nem az erdőssztyepp-zónában, hanem hegyvidéki tölgyeseink övében fejlődtek ki („pannonische Hügelsteppe”, Meusel et al. 1965).

- A középhegységek molyhos tölgyes bokorerdői lombkoronaszintjükben a balkáni cserjéseket képviselik, tisztásaikat viszont keleti sztyeppfajok uralják.

- Ritka kontinentális erdőféleségek és erdőssztyepp-cserjések (Tilio-Fraxinetum, ill. Spiraeetum mediae) zárt erdők övében, elszigetelten máig fennmaradtak.

- Az Alföld, különösen a Duna-Tisza köze egyik legkiterjedtebb növénytársulásába, az évelő nyílt homokpusztagyepbe számos szubmediterrán faj épült be.

Véleményünk szerint a Knapp-féle kategóriák nyelvén értelmezett „keletszubmediterrán elegyes tölgyesek" és a „pontuszi-pannon erdőssztyepp” tartományok Kárpát-medencei átmeneti területén két vegetációkörzet megkülönböztetése lenne célszerủ. Az egyik a nagyobb, kifejezetten szubmediterrán jellegü pannon tölgyerdő - erdőssztyepp körzet, a másik a kisebb kiterjedésủ és erősebb kontinentális vonásokat hordozó erdélyi tölgyerdő - erdőssztyepp körzet.

\section{Irodalomjegyzék}

ANON. 2014: European Commission, Environment 2000: Natura 2000 - Pannonian biogeographical region. URL: http://ec.europa.eu/environment/nature/natura2000/sites_hab/biogeog_ regions/index_en.htm\#pannonian [letöltve 2014.09.15.]

Ardelean A. 1999: Flora şi vegetaţia din valea Crişului Alb. [Flora and vegetation in the Crişul Alb river valley]. Vasile Goldiş University Press, Arad.

BAILEY R. G. 2005: Identifying ecoregion boundaries. Environmental Management 34, Supl. 1: $14-26$.

BARINA Z. 2006: A Gerecse hegység flórája. Rosalia 1, Magyar Természettudományi Múzeum, Duna-Ipoly Nemzeti Park Igazgatóság, Budapest, $612 \mathrm{pp}$.

BARThA D., KirÁLY G. (szerk.) 2015: Magyarország edényes növényfajainak elterjedési atlasza. Nyugat-magyarországi Egyetem Kiadó, Sopron, 330 pp.

Bohn U., Gollub G., HetTwer C. (eds) 2000. Karte der natürlichen Vegetation Europas, 1: 2500 000. Bundesamt für Naturschutz, Bonn-Bad Godesberg.

Borbás V. 1896: Vasvármegye növénygeografiai viszonyai. (Geographia plantarum Comitatus Castriferrei). In SzIKLAY J., Borovszky S. (szerk.) Magyarország vármegyéi és városai, Vasvármegye, Apollo, Budapest, pp. 497-542.

BölöNI J., MolnÁr Zs., KUn A. (szerk.) 2011: Magyarország élőhelyei. A hazai vegetációtípusok leírása és határozója. MTA Ökológiai és Botanikai Kutatóintézete, Vácrátót, 439 pp. 
Bölöni J., MolnáR Zs., Biró M., Horváth F. 2008: Distribution of the (semi-)natural habitats in Hungary II. Woodlands and shrublands. Acta Botanica Hungarica 50 (Suppl.): 107-148. http://dx.doi.org/10.1556/ABot.50.2008.Suppl.6

BoRBÁs V. 1905: Magyarország természetes flórájának tagozódása. In: GYörGY E. (szerk.) A Föld és népei V. Franklin Társulat, Budapest, pp. 99-127.

Borhidi A., JÁrAi-Komlódi M. 1959: Die Vegetation des Naturschutzgebietes des Baláta-Sees. Acta Botanica Hungarica 5: 259-320.

Borhidi A., Kevey B., Lendvai G. 2012: Plant communities of Hungary. Akadémiai Kiadó, Budapest, $544 \mathrm{pp}$.

CHYTRÝ M. 1994: Xerothermic oak forests in the middle Váh basin and in the southern part of the Strážovská hornatina Upland, Slovakia. Scripta Facultatis Scientiarum Naturalium Universitatis Masarykianae Brunensis - Biology 22-23(1992-93): 121-134.

ChytRÝ M. 2012: Vegetation of the Czech Republic: diversity, ecology, history and dynamics. Preslia 84: 427-504.

CHYTRÝ M., HoRÁK J. 1997: Plant communities of the thermophilous oak forests in Moravia. Preslia 68: 193-204.

Chytrý M., Grulich V., TichÝ L., Kouril M. 1999: Phytogeographical boundary between the Pannonicum and Hercynicum: a multivariate landscape analysis in the Podyji/Thayatal National Park, Czech Republic/Austria. Preslia 71: 23-41.

Coldea Gh., Pop A. 1996: Phytocoenolgische Untersuchungen über die meso-thermophilen Eichenwälder Siebenbürgens. Stapfia 45: 55-64.

Csapody I. 1974: Die Agrostio-Quercetum roboris-cerris Wälder der Kleinen Ungarischen Tiefebene. Acta Botanica Hungarica 20: 23-30.

Csü Rös I. 1981: A Nyugati-Szigethegység élővilágáról. Tudományos és Enciklopédiai Kiadó, Bukarest, $304 \mathrm{pp}$.

Didukh Y. P., Fitsailo T. V., Korotchenko I. A., Iakushenko D. M., Pashrevych N. A. 2011: Biotopi lisovoï ta lisostepovoï zon Ukraïni. [Biotopes in the forest and forest-steppe zones in Ukraine]. LLC MACROS, Kyiv.

Diersch Ke H. 1994: Pflanzensoziologie. Grundlagen und Methoden. Eugen Ulmer, Stuttgart, $683 \mathrm{pp}$.

DostÁL J. 1960: The phytogeographical regional distribution of the Czechoslovak flora. Sborn. Čs. Společ. Zeměpis. 65: 193-202.

Dubravková D., Chytrý M., Willner W., Illyés E., Janišová M., Kállayné-Szerényi J. 2010: Dry grasslands in the Western Carpathians and the northern Pannonian Basin: a numerical classification. Preslia 82: 165-221.

Euro+Med 2006-2014: Euro+Med PlantBase - the information resource for Euro-Mediterranean plant diversity. Published on the Internet http://ww2.bgbm.org/EuroPlusMed/ [letöltve 2016.09.15.].

Fekete G., Molnár Zs., Magyari E., Somodi I., Varga Z. 2011: Egyediség, szabályszerüség és deviáció a Pannonian régió vegetációjának példáján. Botanikai Közlemények 98: 29-59.

Fekete G., Molnár Zs., Magyari E., Somodi I., Varga Z. 2014: A new framework for understanding Pannonian vegetation pattern: regularities, deviations and uniqueness. Community Ecology 15: 12-26. http://dx.doi.org/10.1556/ComEc.15.2014.1.2

Fekete G., Király G., Molnár Zs. 2016: Delineation of the Pannonian vegetation region. Community Ecology 17: 114-124. http://dx.doi.org/10.1556/168.2016.17.1.14

Fekete L., Blattny T. 1913: Az erdészeti jelentőségű fák és cserjék elterjedése a Magyar Állam területén. Joerges, Selmecbánya, $793+150$ pp. 
FODOR I. 1960: Az Északkeleti Kárpátok déli vulkanikus előhegyeinek növénytakarója. Botanikai Közlemények 48: 281-283.

FranjIĆ J., ŠKvorc Ž., Filipović K., Vitasović Kosić I. 2005: Phytosociological characteristics of the Quercus cerris forests in East Slavonia. Haequetia 4: 27-35.

Freitag H. (1962): Einführung in die Biogeographie von Mitteleuropa: unter besonderer Berücksichtigung von Deutschland. G. Fischer Verlag, Stuttgart, 214 pp.

FUKAREK P. 1977: Die Gliederung der illyrischen Florenprovinz in natürliche Vegetationsgebiete mit Hilfe der Waldgesellschaften. Centralblatt für das Gesamte Forstwesen 94: 154-162.

FUKARE K P. 1979: Die Pflanzengeographische Abgrenzung des illyrischen vom moesischen Gebiet. Phytocoenologia 6: 434-445.

Fukare K P., Jovanović B. (eds) 1986: Karta Prirodne Potencijalne Vegetacije SFR Jugoslavije, 1: 1 000 000. [Natural potential vegetation of the SFR Jugoslavia, 1: 1000 000]. In: JovanOvić B., Jovanović R., Zupančıč M. (eds), Prirodna Potencijalna Vegetacija Jugoslavije. Ljubljana.

FUTÁK J. 1947: Xerothermná vegetácia skupiny Kňažného Stola (západné Slovensko). [Xerothermic vegetation in the Kňažný Stol district, Western Slovakia]. Spolok sv. Vojtecha, Trnava, 258 pp.

FuTÁK J. 1966: Fytogeografické členenie Slovenska. [Plant geographical partition of Slovakia]. In: FuTÁx J. (ed.) Flóra Slovenska I., SAV, Bratislava, pp. 535-538.

GÁYER Gy. 1925: Vasvármegye fejlődéstörténeti növényföldrajza és a praenorikumi flórasáv. Vasvármegye és Szombathely Város Kultúregyesülete és a Vasvármegyei Múzeum Évkönyve 1: $1-43$.

Geerdes B., Moll G. 1983: Waldgesellschaften der Hainburger Berge und angrenzender Gebiete (Niederösterreich). Verhandlungen der zoologisch-botanischen Gesellschaft Österreich 121: 5-37.

Gомвосz E. 1936: A magyar növénytani irodalom bibliográfiája 1901-1925. Királyi Magyar Egyetemi Nyomda, Budapest, $440 \mathrm{pp}$.

Hegg O., BÉguin C., Zoller H. 1993: Atlas schutzwürdiger Vegetationstypen der Schweiz. Bundesamt für Wald, Umwelt und Landschaft, Bern, $160 \mathrm{pp}$.

Horvat I., Glavač V., Ellenberg H. 1974: Vegetation Südosteuropas. Gustav Fischer, Stuttgart, $768 \mathrm{pp}$.

Horvát A. O. 1980: Potentillo-Quercetum (sensu latissimo) Wälder II. Janus Pannonius Múzeum Évkönyve 24: 11-32.

Horvát A. O. 1981: Potentillo-Quercetum (sensu latissimo) Wälder III. Janus Pannonius Múzeum Évkönyve 25: 31-70.

HoRVÁth-GodÁnY J. 1977: Vegetációrekonstrukció Délnyugat-Szlovákia löszvidékén. PhD tézis, MTA ÖBKI, Vácrátót.

HÜBl E., HolzNer W. 1975: Grundzüge der Vegetationsgliederung Niederösterreichs. Phytocoenologia 2: 312-328.

Ivan D., Doniță N., Coldea G., Sanda V., Popescu A., Chifu T., Boscaiu N., Mititelu D., PaUCĂ-Сomanescu M. 1993: Vegetation potentielle de la Roumanie. Braun-Blanquetia 9: 3-79.

JAKUCs P. 1961: Die phytozönologischen Verhältnisse der Flaumeichen-Buschwälder Südostmitteleuropas. Akadémiai Kiadó, Budapest, 313 pp.

JAKUCS P. 1985: Ecology of an oak forest in Hungary. Results of „Síkfőkút” Project. Akadémiai Kiadó, Budapest, 545 pp.

JÁvorKa S. 1924-1925: Magyar Flóra. Studium, Budapest, 1307 pp.

JÁvor KA S. 1940: Növényelterjedési határok a Dunántúlon. Mathematikai és Természettudományi Értesítő 59: 968-997. 
JEANPLONG J. 1956: Flóraelemek szerepe a fórahatárok megvonásában Északnyugat-Dunántúlon. Botanikai Közlemények 46: 261-266.

Jovanović B. 1997: The order of downy oak forests Quercetalia pubescentis Br.-Bl. (1931) 1932. In: SARIĆ M., VAsIĆ O. (eds) The vegetation Vegetation of Serbia. Forest communities I. Serbian Academy of Sciences and Arts, Department of Natural and Mathematical Sciences, Beograd, pp. 2-106.

Jovanović B., Jovanović R., Zupančič M. (eds) 1986: Prirodna potencijalna vegetacija Jugoslavije. [The natural potential vegetation of Yugoslavia]. Naučno veće Vegetacijske karte Jugoslavije, Ljubljana.

KÁDÁR L. 1965: Biogeográfia. Tankönyvkiadó, Budapest, 408 pp.

KAPLAN Z. 2012: Flora and phytogeography of the Czech Republic. Preslia 84: 505-573.

KARÁcsonYi K. 2010: Cseres-tölgyes és mészkerülő tölgyes erdők a Tasnádi-dombvidéken (Erdély, Románia). Kanitzia 17: 151-178.

KARÁCSONYI K. 2011: Flora şi vegetatia dealurilor Tăşnadului şi a colinelor marginale. [Flora and vegetation of Dealurile Tăşnadului and its environs]. „Vasile Goldis” University Press, Arad, $368 \mathrm{pp}$.

KARÁCSONYi K., Negrean G. 2014: Szubtermofil flóraelemek expanziós útvonalai a Szilágyságban (Salaj) és környékén (Erdély, Románia). In: Schmidt D., Kovács M., BARTha D. (eds) Absztraktok. 10. Aktuális Flóra- és Vegetációkutatás a Kárpát-medencében, Sopron, pp. 29-30.

KÁRPÁTI Z. 1958: Über die westungarisch-burgenländischen Florengrenzen. Botanikai Közlemények 47: 313-321.

KÁRPÁTI Z. 1960: Die pflanzengeographische Gliederung Transdanubiens. Acta Botanica Hungarica 6: 45-53.

Karrer G., Kilian W. 1990. Standorte und Waldgesellschaften im Leithagebirge, Revier Sommerein. Mitteilungen der Forstlichen Bundesversuchsanstalt Wien 165, Wien, 244 pp.

KerNer A. 1871: Können aus Bastarden Arten werden? Oesterreichische Botanische Zeitschrift 21: 34-41. https://doi.org/10.1007/bf01802624

Kerner A. 1887: Allgemeine Naturkunde. Pflanzenleben. Bibliographisches Institut, Leipzig, 734 $+896 \mathrm{pp}$.

Kerner A., Wettstein R. 1888: Florenkarte von Österreich-Ungarn. Hölzel, Wien.

Kevey B. 2008: Magyarország erdőtársulásai. Tilia 14: 1-488.

KeVey B. 2011: A Bakonyalja homokvidékének erdei III. Homoki cseres-tölgyesek (AsphodeloQuercetum roboris [Borhidi et Járai-Komlódi 1959] Borhidi in Borhidi - Kevey 1996). Folia Musei historico-naturalis Bakonyiensis 28: 9-37.

Kilian W., Müller F., Starlinger F. 1994: Die forstlichen Wuchsgebiete Österreichs. Eine Naturraumgliederung nach waldökologischen Gesichtspunkten. Forstliche Bundesversuchsanstalt, Waldforschungszentrum, Bericht 82 , Wien, $60 \mathrm{pp}$.

Király A., Király G. 2008: Vegetationsmuster von Waldpflanzen am Südwestrand der Kleinen Ungarischen Tiefebene. Neilreichia 5: 19-109.

KIRÁLY G. (szerk.) 2009: Új magyar füvészkönyv. Magyarország hajtásos növényei. Határozókulcsok. Aggteleki Nemzeti Park Igazgatóság, Jósvafö, 616 pp.

Király G., Szmorad F. 2004: A Soproni-hegység növényföldrajzi viszonyai. Flora Pannonica 2(2): 22-36.

Király G., KUn A., SZMORAD F. 1999: A Vas-hegy csoport vegetációja és florisztikai érdekességei. Kitaibelia 4: 119-142.

Király G., MolnÁr Zs., Bölöni J., CsıKy J., Vojt Kó A. (eds) 2008: Magyarország földrajzi kistájainak növényzete. MTA Ökológiai és Botanikai Kutatóintézete, Vácrátót, 248 pp. 
Fekete G. et al.

KNAPP S. 2005: Biogeography - space, form and time. Journal of Biogeography 32: 3-4. https://doi.org/10.1111/j.1365-2699.2004.01229.x

Koó A. (1994): Pflegekonzept für die Naturschutzgebiete des Burgenlandes. Biologisches Forschungsinstitut Burgenland. Biologische Station Neusiedlersee, Illmitz, 203 pp.

KovÁcs M. 1975: Beziehung zwischen Vegetation und Boden (Die Bodenverhältnisse der Waldgesellschaften des Mátragebirges). Akadémiai Kiadó, Budapest, 364 pp.

Kovács M., Podani J. 1979: Zönologische Untersuchung der Traubeneichen-Zerreichenwälder der Tarna-Gegend (Nordungarisches Mittelgebirge). Phytocoenologia 6: 439-454.

Kun A., Ruprecht E., Szabó A. 2004: Az Erdélyi-medence bioklimatológiai jellemzése. Erdélyi Múzeumi Füzetek 13: 63-81.

KÜCHLER A. W. 1973: Problems in classifying and mapping vegetation for ecological regionalization. Ecology 54: 512-523.

KüCHLER W. 1985: Potential natural vegetation, 1: 7 7,500 500,000 scale. In: National Atlas of the United States. Department of the Interior, US Geological Survey, Reston, Virginia.

LAVRENKo Ye M 1959: Main regularities of phytocenoses and ways of their studies. Field Geobotanics 1: 13-75.

Majer A. 1980: A Bakony tiszafása. Akadémiai Kiadó, Budapest, 373 pp.

MARINČEK L. 1995: Contribution to demarcation and phytogeographic division of the Illyrian floral province, based on vegetation and flora. Gortania 16: 99-124.

MedWeCKA-KornAś A. 1959: Roślinność rezerwatu stepowego „Skorocice” Koło Buska. Ochrony przyrody 26, Drukarnia Universytetu Jagiellonskiego, Kraków, 89 pp.

Meusel H., JÄGer E., Weinert E. 1965: Vergleichende Chorologie der zentraleuropäischen Flora I. Gustav Fischer, Jena, Stuttgart, New York.

Michalko J., Berta J., Magic D., MaglockÝ Š. 1979: Potenciálna prirodzená vegetácia, 1: 500 000. [Potential natural vegetation, $1: 500$ 000]. SAV, Bratislava.

Michalko J., Magic D., Berta J., Maglocký Š., Spáni ková A. 1984-1986: Geobotanical map of CSSR, Slovak Socialist Republic. Maps. VEDA, Bratislava.

Michalko J., Magic D., Berta J., Rybníček K., Rybníčková E. 1987: Geobotanical map of CSSR. Slovak Socialist Republic. VEDA, Bratislava.

Mikyška R., Deyl M., Holub J., Husová M., Moravec J., Neuhäusl R., NeuhäuslováNovotnÁ Z. 1968-1972: Geobotanická mapa CSSR 1. Ceské Zemé. [Geobotanical map of the CSSR I. Czech lands]. Akademia, Praha.

Moesz G. 1911: Adatok Bars vármegye flórájához. Botanikai Közlemények 10: 171-185.

Molnár Cs., Molnár Zs., Barina Z., Bauer N., Biró M., Bodonczi L., Csathó A. I., Csiky J., DeÁk J. Á., Fekete G., Harmos K., Horváth A., Isépy I., Juhász M., Kállayné Szerényi J., Király G., Magos G., Máté A., Mesterházy A., Molnár A., Nagy J., Óvári M., Purger D., Schmidt D., Sramkó G., Szénási V., Szmorad F., Szollát Gy., Tóth T., Vidra T., Virók V. 2008: Vegetation-based landscape regions of Hungary. Acta Botanica Hungarica 50 (Suppl.): 47-58. http://dx.doi.org/10.1556/ABot.50.2008.Suppl.4

Molnár Zs., Kun A. (szerk.) 2000: Alföldi erdőssztyeppmaradványok Magyarországon. WWFMTA ÖBKI, Budapest-Vácrátót, 56 pp.

Mucina L., Grabherr G., Wallnöfer S. 1993: Die Pflanzengesellschaften Österreichs III. Wälder und Gebüsche. Gustav Fischer Verlag, Jena, Stuttgart, New York, 353 pp.

NiKLFELD H. 1964: Zur xerothermen Vegetation im Osten Niederösterreichs. Verhandlungen der zoologisch-botanischen Gesellschaft Wien 103-104: 152-181.

Niklfeld H. 1974: Natürliche Vegetation. In: BreU J. (ed.) Atlas der Donauländer. Deuticke, Wien, p. 171. 
NikLfeld H. 1993: Pflanzengeographische Charakteristik Österreichs. In: MUCina L., GraBHerr G., Wallnöfer S. (eds.) Die Pflanzengesellschaften Österreichs I. Gustav Fischer Verlag, Jena, Stuttgart, New York, pp. 43-75.

Oliviero J., Márquez A. L., ReAl R. 2013: Integrating fuzzy logic and statistics to improve the reliable delimitation of biogeographic regions and transition zones. Systematic Biology 62: 1-21. http://dx.doi.org/10.1093/sysbio/sys061

PoP I. 1967: Studiu comparativ asupra ceretelor din cimpia inaltă Miersigului şi de pe dealurile piemontane crişene. Contribuții Botanice, Cluj.

Pop I., Ardelean A., Codoreanu V., Crişan A., Csürös-Káptalan M., Csürös S., Ghişa E., Hodişan I., Ratiu O., SzÁsz E. 1978: Flora şi vegetaţia Munţilor Zarand. [Flora and vegetation of the Zarand Mts]. Contribuții Botanice 18: 1-215.

Pócs T. 1960: Die zonalen Waldgesellschaften Südwestungarns. Acta Botanica Hungarica 6: 75-105.

Pócs T. 1981: Magyarország növényföldrajzi beosztása. In: HorToBÁGyi T., SimON T. (szerk.) Növényföldrajz, társulástan és ökológia. Nemzeti Tankönyvkiadó, Budapest, pp. 120-155.

Purger D., Lengyel A., Kevey B., Lendvai G., Horváth A., Tomić Z., Csiky J. 2014: Numerical classification of oak forests on loess in Hungary, Croatia and Serbia. Preslia 86: 47-66.

RapaICs R. 1910: Magyarország növényföldrajzi tagozódása. Pótfüzetek a Természettudományi Közlönyhöz 97: 34-41.

RoleČé J. 2005: Vegetation types of dry-mesic oak forests in Slovakia. Preslia 77: 241-261.

SChmithüsen J. 1968: Allgemeine Vegetationsgeographie. 3. Auflage. De Gruyter, Berlin.

SimonKai L. 1910: Magyarország növényföldrajzi térképe; a szerző hagyatékából ismertette Tuzson J., Botanikai Közlemények 9: 251-255.

Soó R. 1932: Florenkarte Europas. Pflanzenareale III. Heft 7, Karte 1.

Soó R. 1933: Floren- und Vegetationskarte des historischen Ungarns. A Debreceni Tisza István Tudományos Társaság Honismertető Bizottságának Kiadványai 8: 5-35.

Soó R. 1945: Növényföldrajz. Magyar Természettudományi Társulat, Budapest, 205 pp.

Soó R. 1947: Flora Carpato-Pannonica. Acta Geobotanica Hungarica 6: 114-117.

Soó R. 1961: Neue floristisch-geobotanische Einteilung Ungarns. Annales Universitatis Scientiarum Budapestinensis de Rolano Eötvös nominatae, Sectio Biologica 4: 155-166.

Soó R. 1963: Systematische Übersicht der pannonischen Pflanzengesellschaften VI. Die Gebirgswälder II. Acta Botanica Hungarica 9: 123-150.

Soó R., Jávorka S. 1951: A magyar növényvilág kézikönyve. Akadémiai Kiadó, Budapest, 1120 pp.

Szmorad F. 1994: A Kőszegi-hegység erdőtársulásai. In: BARTHA D. (ed.) A Kőszegi-hegység vegetációja. Erdészeti és Faipari Egyetem, Sopron, pp. 106-132.

TALLós P. 1959: Erdő- és réttípusok a Széki-erdőben. Erdészeti Kutatások 6: 301-353.

Tuzson J.1915: A Magyar Alföldnövényföldrajzitagolódása. Mathematikaiés Természettudományi Értesítő 33: 143-220.

WALLNÖFER S. 2003: Thermophile Eichenwaldgesellschaften im Osten Österreichs. Verhandlungen der zoologisch-botanischen Gesellschaft Österreich 140: 1-16.

WAlter H., BreCKLE S.-W. 1986: Ökologie der Erde: Geo-Biosphäre, 3. Spezielle Ökologie der gemäßigten und arktischen Zonen Euro-Nordasiens. Gustav Fischer, Stuttgart.

WALTER H., STRAKa H. 1970: Arealkunde. Floristisch-historische Geobotanik. Ulmer, Stuttgart, $478 \mathrm{pp}$.

Willner W. 2013: Pannonische Steppenrasen in Österreich. In: BAumbaCH H., Pfüt ZenReUter S. (eds) Steppenlebensräume Europas. Gefährdung, Erhaltungsmassnahmen und Schutz. Thüringer Ministerium für Landwirtschaft, Forsten, Umwelt und Naturschutz, Erfurt, pp. 151-162. 
Wraber M. 1969: Pflanzengeographische Stellung und Gliederung Sloweniens. Vegetatio 17: 176-199. https://dx.doi.org/10.1007/bf01965908

Zhang X. (ed.) 2007: Vegetation Map of the People's Republic of China, 1:1.000.000.000. The Geological Publishing House, Beijing.

ZóLYOMi B. 1941: Adatok a Kisalföld növényföldrajzának ismeretéhez. Botanikai Közlemények 38: $95-96$.

ZóLYOMI B. 1967: Rekonstruált növénytakaró, 1: 1,5 millió. In: RaDó S. (szerk.) Magyarország Nemzeti Atlasza. Kartográfiai Vállalat, Budapest.

Zólyomi B. 1989: Természetes növénytakaró, 1: 1500 000. In: PÉcsi M. (szerk.) Magyarország Nemzeti Atlasza. Kartográfiai Vállalat, Budapest, p. 89.

\title{
Delineation of the Pannonian vegetation region
}

\author{
G. FEKETE, G. KIRÁLY ${ }^{1}$, Zs. MOLNÁR ${ }^{2 *}$ \\ ${ }^{1}$ Institute of Silviculture and Forest Protection, University of Sopron, \\ Ady E.u. 5, H-9400 Sopron; kiraly.gergely@uni-sopron.hu \\ ${ }^{2}$ MTA Centre for Ecological Research, Institute of Ecology and Botany, Alkotmány u. 2-4, \\ H-2163 Vácrátót; molnar.zsolt@okologia.mta.hu
}

Accepted: 20 April 2017

Key words: flora, Pannonian vegetation types, potential natural vegetation, Quercetum petraeae-cerridis, vegetation geography, vegetation map, zonality.

Biogeographical regions have been delineated traditionally on the basis of the flora. However, the potential natural vegetation is also suitable to delineate regions. Here we discuss the boundaries of the recently established Pannonian vegetation region based on the distribution of characteristic vegetation types. The boundary of the region runs usually between the Quercus cerris-Quercus petraea and Carpinus betulus or Fagus sylvatica dominated areas. We describe the potential vegetation on both sides of the boundary. The region has an area of ca. $167,000 \mathrm{~km}^{2}$. Often, the boundary does not coincide with the boundary of the Pannonicum floristic province. Our map provides an opportunity to the European Union to use a scientifically more sound delineation of the Pannonian region in her Natura 2000 and other programs.

* Corresponding author. 